\title{
A CONQUISTA DO TEMPO NOTURNO: Porto Alegre "moderna"
}

\author{
Núncia Santoro de Constantino*
}

O processo de urbanização no Rio Grande do Sul é esboçado na primeira metade do século XIX, justamente quando o fenômeno urbano acelera-se na Europa. Na segunda metade do mesmo século, desenvolve-se na Província a idéia de cidade como estilo de vida. Assiste-se a implantação de padrões culturais citadinos, influenciados por imagens do Velho Continente.

Porto Alegre, que nas origens apresentara características das cidades luso-brasileiras, é atingida por influências diversas que trazem efeitos cosmopolitas em arquitetura e urbanismo, a exemplo de outras cidades, como Pelotas e Rio Grande. ${ }^{1}$

De um modo geral, o amplo desfrute do tempo noturno é novidade que se desenvolve no século XIX, com o crescimento e urbanização das cidades. As reformas que se verificaram na plástica das grandes capitais européias tornaram a rua bonita e confortável. Pouco a pouco, espaços públicos passaram a funcionar como prolongamento de ambientes privados.

* Professora do Depto. de História - IFCH-PUCRS

1 Laudelino Medeiros. O processo de urbanização no Rio Grande do Sul. Porto Alegre:

Faculdade de Filosofia/Universidade do Rio Grande do Sul, 1959.

Estudos Ibero-Americanos. PUCRS, v.XX, n.2, p. 65-84, dezembro, 1994 
Gonçalves Chaves, em memórias publicadas pela primeira vez em 1822, registra que a recém feita cidade "(...) é a praça da Província que tem produtos mais variados para exportação e consumo". ${ }^{8}$ Rio Pardense de Macedo escreve que a Vila, antes disto, já fora uma "esquina da Província, recebendo e enviando utilidades e mantimentos necessários aos crescentes centros povoados em torno de Rio Grande e de Rio Pardo". 9

O núcleo urbano crescera rapidamente nas duas primeiras décadas do século IX. Tal crescimento foi conseqüência, sobretudo, da ampliação da lavoura tritícola; Porto Alegre tornara-se o principal centro exportador. ${ }^{10}$

A decadência da lavoura tritícola faz com que a cidade fique em plano secundário frente ao porto do Rio Grande. Paul Singer afirma que "(...) entre 1820 a 1858 Porto Alegre vegeta e que as exportações de São Leopoldo serviram para reativar as atividades comerciais". ${ }^{11}$ Telmo Moure acredita que a cidade dá um salto na segunda fase da colonização alemã, isto é, entre 1840 e 1870 , fase que se caracteriza pela produção de excedentes comercializáveis. A capital tornara-se o mercado consumidor para as colônias alemãs nos meados do século passado. ${ }^{12}$

Porto Alegre cidade fortificada na primeira metade do século passado e as fortificações orientaram a organização do espaço e o crescimento urbano; poucas ruas eram empedradas, inexistentes os serviços públicos como água potável, esgotos ou iluminação. À noite, quando não havia lua, era a escuridão total.

\section{Focos de luz mortiça}

Só em 1834 foram instalados os primeiros lampiōes, precisamente duzentos lampiões de óleo de baleia, presos por ferragens nas paredes de

8 Antonio José Gonçalves. Memórias economo-políticas da administração pública do Brasil. Porto Alegre: Cia. União de Seguros Gerais, 1978. p. 114.

9 Francisco Riopardense de Macedo. Porto Alegre: origem e crescimento. Porto Alegre: Sulina, 1968, p. 77.

10 Elmar Manique da Silva. Ligações externas da Economia Gaúcha (1736-1890). In: DACANAL, José Hildebrando, GONZAGA, Sergius (org.) RS economia e política. Porto Alegre: Mercado Aberto, 1979, p. 77.

11 Paul Singer. Desenvolvimento econômico e evolução urbana: análise da evolução econômica de São Paulo, Blumenau, Porto Alegre, Belo Horizonte e Recife. São Paulo: Nacional/Ed. da Universidade de São Paulo, 1968, p. 161.

12 Telmo Moure. A Inserção do Imigrante na Economia Agrícola. In: LANDO, Aldair Marli (org.) RS: Imigração e colonização. Porto Alegre: Mercado Aberto, 1980, p. 96. 
determinadas casas, em pouco tempo desativados em virtude do mau funcionamento. A precária iluminação, cujo combustível era óleo de peixe, foi reestabelecida em 1838 e acompanhou com defasagem o crescimento da cidade. Nos meados do século houve inovações do serviço, mas as reclamaçōes continuavam. O novo sistema, além de oneroso e deficiente, não acompanhava as necessidades crescentes da cidade. Em 1864, utilizou-se querozene como combustível, mas a noite porto-alegrense permanecia muito escura. $^{13}$

Para que a noite fosse interditada, além da escuridão havia o toque de recolher. Às nove horas da noite no inverno e às dez no verão, soavam os sinos da Matriz. Só poderia permanecer à rua quem fosse portador de especial autorização.

Durante a metade do século passado, os "largos" eram espaços para as socialidades públicas: Quitandas, Ferreiros, Pelourinho, Largo do Arsenal. Neles se desenvolvia a atividade urbana, os eventos da vida social, como as festas que eram basicamente religiosas. Chamou a atenção de Hörmeyer, soldado alemão que descreve a cidade em 1850, a inconveniência dos espetáculos pirotécnicos diurnos.

"Nos dias de festas altas, o respectivo 'Santo' é levado em procissão; pessoas mascaradas acompanham-no; são queimados fogos de artifício, tanto na véspera como no próprio dia da festa, nāo importando que, de dia claro e com sol luminoso, se estoure pólvora por uns 100 ou 1000 mil-réis, sem ter-se outro prazer a não ser o estouro e a fumaça". ${ }^{14}$

Lembra ainda o militar que "teatros, soirées, círculos, cassinos ou harmonias assim como qualquer espécie de entretenimento espirituoso, faltam aqui completamente". Hörmeyer não teria sido convidado para os exclusivos saraus privados, a que fazem referência outros viajantes, como Saint-Hilaire e Avé-Lallemant.

É bem verdade que o entretenimento público quase sempre está lembrado à luz do dia e aos domingos. Oficialmente a noite é desconhecida.

Tome-se como fonte o Professor Coruja, minucioso memorialista das primeiras décadas do século XIX; a cidade por ele evocada teria seus 12.000

13 Sérgio da Costa Franco. Porto Alegre: guia histórico. Porto Alegre: Ed. da Universidade/UFRGS, 1992, p. 213-14

14 Joseph Hörmeyer. O Rio Grande do Sul de 1850: descrição da Província do Rio Grande do Sul no Brasil Meridional. Porto Alegre: Luzzato/Eduni-Sul, 1980, p. 76. 
habitantes. Lambrando a origem da denominação "Beco do Leite", escreveu que ali residiu muito tempo o alfaiate Manoel José Leite "que diziam ser amigo de boas patuscadas aos domingos com os rapazes e caixeiros daquele tempo". Menciona uma famosa casa onde moravam "umas moças cantadeiras, e que dizem que cantavam bem, aonde aos domingos iam os moços passear". No candomblé da Mãe Rita, "(...) se reuniam no domingo à tarde pretos de diversas naçōes. (...) cantavam e dançavam...". ${ }^{15}$

\section{Noite ignorada}

Uma vez Coruja aponta para o entretenimento noturno, com cautela. Usa nome fictício para contar que determinado rapaz "quis fazer de um domingo um dia cheio". Narra todos os passeios realizados pelo personagem e escreve que "... saiu de passeio à noite na rua da Praia... ao passar pelo armazém do Pescocinho, foi reconhecido pelo Lino Calafate que na porta imediata arrebanhava rapazes para dançarem com a moças que aí havia juntado...". ${ }^{16}$

Nosso espirituoso e atento cronista esquece praticamente a noite, mas não deixa de lembrar as mulheres que à mesma noite são associadas:

"As Potreiras e as Tagarras que se tinham encurralado no Beco do Fanha, (...) as duas ex-atrizes Angelica Lindeza e a Coxifã, a Cabra-Roxa e a cisplatina Fragata Imperatriz (...) a Imperatriz (...), a Antonica Talavera (...) e a Botoa (...) a Jacaroa". ${ }^{\text {? }}$

Coruja lembra uma determinada casa de porta-e-janela, no final da rua da Igreja, onde morava a Felizarda, conhecida como "não-sei-o-quê-debronze", que acabou por emprestar seu apelido a lugar da cidade: Alto da Bronze. $^{18}$

Eram essas as mulheres que ofereciam prazeres por sussurros, que convidavam de vãos escuros de janelas dos mal-afamados becos. Algumas delas com o passar do tempo, transformaram-se nas célebre alcoviteiras, mulheres rebuçadas em mantilhas que conduziam à casa de alcouce, intermediárias de amores clandestinos. ${ }^{19}$

15 Antônio Álvares Pereira Coruja. Antigualhas: reminiscências de Porto Alegre. Porto Alegre: Cia. União de Seguros Gerais, 1983, p. 21, 22, 23, 26.

16 Id. Ibid, p. 35.

17 Id. Ibid, p. 79.

18 Id. Ibid. 


\section{Noite tenebrosa}

Sobrenatural, crime, pecado, enfim, o que representa o perigo, são desde sempre imagens associadas à noite. Inúmeros provérbios ensinam a temer e a evitar a escuridão, porque a noite foi feita para dormir, de noite todos os gatos são pardos e, ademais, Deus ajuda a quem cedo madruga.

Cuidado com a noite. $\mathrm{O}$ homem é sensorialmente desprovido para enfrentar a escuridão, tanto a da rua, como a da alma. Porque as profundezas da alma são também aterrorizantes. Veja-se a Noite de Valpúrgis. Goethe sintetiza o legendário, buscando na celebração das bruxas uma evocação para o mal com que pretende retratar as profundezas escuras da alma de Fausto. Noite, escuridão e mal são razões para o medo.

Não seria diferente a concepção do noturno na mais meridional das províncias brasileiras, a julgar pela expressão empregada por Caldre e Fião, autor gaúcho do segundo romance brasileiro, A Divina Pastora, publicado em 1847, tendo Porto Alegre como cenário. Almênio atende sua prima Edélia, por quem nutre secreta paixão, quando essa lhe pede que busque um médico para salvar a vida do homem amado. O infeliz mancebo "(...) duas horas depois voltava com o cirurgião. Não temera o horror da tenebrosa noite". ${ }^{20}$

São tantos os perigos noturnos que o medo na escuridão se transformou em medo da escuridão. Escreve Delumeau: "(...) o desaparecimento da luz nos confina ao isolamento, nos cerca de silêncio (...). Nossa civilização urbana, auxiliada pelo cientificismo que se desenvolveu a partir do século XVIII, esforçou-se "para fazer recuar o domínio da sombra e prolongar o dia por meio de uma iluminação artificial". ${ }^{21}$

19 Achylles Porto Alegre. Jardim de saudades. Porto Alegre: Wiedmann, 1921, p. 21. Eram mulheres que poderiam fazer com que fosse enfrentado o medo da noite.

20 Caldre e Fião. A divina pastora. Porto Alegre: RBS, 1992, p. 65.

21 Jean Delumeau. O medo no Ocidente (1300-1800). São Paulo: Cia. das letras, 1989, p. 75 . 


\section{LUMINOSIDADE}

\section{Modernização do meio urbano}

Nos meados do século XIX, são significativos os melhoramentos implantados na capital. Funda-se a Hydraulica que fornece água aos domicílios ou nos chafarizes públicos a partir de 1865. Os Largos passam por reformas para aformoseamento, sendo que o Largo do Arsenal é transformado na Praça da Harmonia, onde se plantam árvores e se colocam bancos de madeira, para o recreio da população. O Theatro São Pedro passa a ser opção para o divertimento noturno.

Construía-se o Theatro quando Hörmeyer esteve em Porto Alegre. Observou o viajante que outro teatrinho funcionava em velha e arruinada casa. ${ }^{22}$ Não teria sido capaz de perceber que as representações eram antiga paixão dos porto-alegrenses. Desde o início da povoação foram organizados grupos amadores para encenaçōes teatrais. Em 1794 foi construída a primeira casa para espetáculos que recebeu o nome de Casa da Comédia. Athos Damasceno informa que, antes, foram representadas peças populares portuguesas. Seriam representaçōes à luz do dia, levadas à cena nos largos. Em 1797 algumas inovaçōes foram intoduzidas na Casa da Comédia que passou a ser chamada Casa da Ópera. ${ }^{23}$

Eram extremamente luxuosas as instalações do São Pedro para a cidadezinha com cerca de 20.000 habitantes. Augusto Porto Alegre recordou a grande noite da inauguração. Registra que compareceu "a fina flor da sociedade (...) O teatro vistosamente ornamentado todo inundado num banho de luz, em abundância derramada dum lustre suspenso do centro da cúpula, tendo 48 mangas dispostas em duas ordens..." O programa foi de alto nível: orquestra 24 membros preencheu os intervalos do espetáculo, encenado pela Companhia Ginásio Dramático Rio-Grandense que apresentou Recordações da Mocidade. ${ }^{24}$

Porto Alegre crescia a olhos vistos na década em que o Theatro foi inaugurado. Organizava-se o comércio nos moldes das cidades desenvolvidas; em 1858 fundou-se a Praça do Comércio, que deu origem à Associação

22 Joseph Hörmeyer. Op. Cit, p. 75

23 Athos Damasceno. Palco, salão e picadeiro: em Porto Alegre no século XIX. Porto Alegre: Globo, 1956, p. 3-6-43.

24 Id. Ibid, p. 54 
Comercial. Costa Franco assinala que a Guerra do Paraguai oportunizara bons negócios, tendo inclusive estimulado o surgimento de indústrias. ${ }^{25}$

O sistema ferroviário aproximaria os mercados, facilitando o escoamento da produção. Em 1874 é implantada a primeira linha férrea, ligando Porto Alegre a São Leopoldo. Até 1886 houve vários e importantes melhoramentos, como a construção do Gasômetro, regularização da coleta de lixo, implantação de serviços telefônicos. Linha regular de bondes de tração animal entrara em funcionamento. Os arraiais cresciam e recebiam nomes: Menino Deus, Cidade Baixa. As antigas estradas são incorporadas à estrutura urbana, transformam-se em arrabaldes: São Manuel, São João, Navegantes, Partenon.

Singer aponta a evolução da cidade como consequêencia da colonização alemã, não só pelo intercâmbio com as colônias, mas sobretudo porque o capital nelas acumulado passou a ser investido em empreendimentos comerciais importantes com sede em Porto Alegre. ${ }^{26}$

Quando foi instaurado o novo regime político, a movimentação comercial e industrial da cidade era considerada notável. Havia três estabelecimentos bancários, trinta e sete armazéns atacadistas e trinta e três para vendas no varejo; dez casa de tecidos por atacado, cinqüenta e seis varejistas, além de dez lojas para venda de livros ou miudezas. Em 1890 funcionavam sete fábricas de velas, uma de sabonetes, oito de tamancos, uma de vidros, cinco de fogos de artifício, uma de escovas e vassouras, uma de espartilhos, duas de licores, duas de carros, uma de camisas, dezoito de charutos, seis de chapéus, duas de cadeiras, três de águas gasosas, além de sessenta e três olarias. $^{27}$

O censo de 1872 apontara 43.998 habitantes entre livres e escravos; em 1890, verificou-se que Porto Alegre contava com 73.674 habitantes. Comparando-se o último número com aquele do senso de 1848, ou seja, 28.330 habitantes em todo o município, constata-se que pouco faltou para a população triplicar. ${ }^{28}$ Para o incremento populacional, a imigração foi fator da maior importância nas últimas duas décadas do século.

25 Sérgio da Costa Franco. Porto Alegre e seu comércio. Porto Alegre: Associação Comercial, 1983, p. 55

26 Paulo Siger. Op. cit, p. 105.

27 Enciclopédia dos município brasileiros. v. 34. Rio de Janeiro: IBGE, 1959, p. 68.

28 Fundação de Economia e Estatística. De Província de São Pedro e Estado do Rio Grande do Sul; censos do RS 1803-1950. Porto Alegre, 1981. 
O viajante francês Saint-Hilaire registra que a cidade é influenciada por alemāes nos anos trinta. Mesmo antes, Carl Seidler escreve que Porto Alegre é o melhor mercado para a colônia de São Leopoldo; os muitos franceses e ingleses domiciliados na capital cultivam hábitos de consumo que animam a atividade produtiva dos alemães. ${ }^{29}$ Avé-Lallemant observaria, em 1858, a presença maciça de alemães na cidade que definiu como meio germanizada. Os italianos começaram a ingressar em grande número a partir de 1875 ; em 1893 eram cerca de 6.000 na cidade, aproximadamente $10 \%$ da população. $^{30}$

Diégues Júnior afirma que, sendo Porto Alegre a capital do Rio Grande do Sul, para onde se dirigiam as maiores correntes migratórias, era natural que a cidade recebesse "... a influência cultural, tanto econômica como social, do elemento imigrado. ${ }^{31}$

\section{Sociedades noturnas}

Os melhoramentos urbanos implementados em Porto Alegre na segunda metade do século incluíam iluminação pública. Em 1867 foi contratada iluminação pelo sistema de gás hidrogênio, produzido em estação apropriada. Inaugurou-se em 1874, com 500 combustores, a maioria usada na área central. ${ }^{32}$ Ampliavam-se os focos de claridade noturna com luz de melhor qualidade.

A mais comum e recomendável forma de distração noturna continuava a ser o serão doméstico. Permanecia a família em casa, escutando estórias ou algum trecho de leitura. Quando havia visitas, promoviam-se recitativos ao piano: sonetos eram declamados ao som de peças musicais. Servia-se chá ou licores, com doces e biscoitos. Sendo maior o número de convidados, grande variedade de iguarias permanecia à mesa da varanda: quindins, doces em compoteiras, queijadinhas, pão-de-ló. Licores ficavam à exposição no etager. O infalível piano animava as danças que eram valsas, havaneiras, shotings ou polcas, czardas, o velho minueto. Nos intervalos jogavam-se as

29 Carl Seidler. Dez anos no Brasil. Belo Horizonte: Itatiaia; São Paulo: Ed. da Universidade de São Paulo, 1981.

30

Núncia Santoro de Constantino. O italiano da esquina: imigrantes na sociedade porto-alegrense. Porto Alegre: EST, 1991, p. 59.

31 Manuel Diégues Júnior. Imigração, urbanizaçāo, industrialização. Rio de janeiro: Instituto Nacional de Estudos Pedagógicos, 1964, p. 245.

Sérgio da Costa Franco. Porto Alegre: guia histórico, p. 214. 
prendas, tiravam-se sortes e adivinhações. Era o sarau. ${ }^{33}$ Estas reuniōes privadas permaneceram comuns durante longo tempo.

Lembrando a cidade de 1901, registrava De Francesco que, à noite, rara era a sala de casa que não estivesse iluminada às quintas-feiras e aos sábados, com piano dedilhado por "mãozinhas gentís". ${ }^{34}$ Se o piano reinava em casa, no posto de honra da sala, na rua reinava o violão. Pelas alamedas da Praça da Harmonia, recém-ajardinada e urbanizada à beira do Guaíba, caminhavam alguns notívagos dedilhando violōes, por vezes com alarido indesejável, pois foram proibidas as serenatas por Barros Cassal, nos primeiros tempos da república. ${ }^{35}$

Mas outra formas de diversão tornavam-se comuns no decorrer do terceiro quartel do século. Imigrantes alemães fundaram sociedades recreativas que somaram às antigas bailantes. Em 1855 foi fundada a Sociedade Germânia, menos de dez anos depois funcionava a Leopoldina, cujo nome prestava homenagem à primeira imperatriz do Brasil. En noites de sábado aconteciam os kerbs, com foguetório anunciando a festa que varava a noite. ${ }^{36}$ Costumes e tradições estavam sendo transplantados, como é o caso de peculiares reuniōes masculinas.

Na antiga chácara do Bier, na Azenha, o alemão Obst criou um lugar de diversão para seus patrícios. No Sans Souci jogava-se bolão à tardinha, bebia-se cerveja, entoavam-se velhas cançōes enquanto a noite avançava. ${ }^{37}$ Mais tarde surgiu o Recreio Harmonia, na Várzea, em chácara da frau Scheid, onde sonoros grupos se divertiam servidos pela proprietária. Restaurantes e bares típicos alemães foram aparecendo na cidade; Westphalia, Limburgo, Bierstuben, Heidelberg, Strammen Hund. ${ }^{38}$

Antes o que havia eram casas de pasto, junto a estalagens, nos becos escuros ou perto das docas. Com referências às primeiras décadas do século, Coruja é capaz de lembrar os taverneiros que havia na cidade: o Grumatã,o Angolista, o Zé das Negras, o Manuel das Mulatas, o Joảo Marinheiro, o Compra Bicos e o Manuel Beriberi. ${ }^{39}$ No início do período republicano,

33 Achyles Porto alegre. Op. cit.

34 José De Francesco. Reminiscências de um artista. Porto Alegre, 1961, p. 13

35 Achyles Porto Alegre. Flores entre ruinas. Porto Alegre: Wiedmann, 1920, p. 171.

36 Ary da Veiga Sanhudo. Porto Alegre: crônicas da minha cidade. Porto Alegre: Movimento/IEL, 1975, p. 20.

37 Achyles Porto Alegre. Seröes de inverno. Porto Alegre: Selbach, 1923, p. 109.

Athos Damasceno Ferreira. Imagens sentimentais da cidade. Porto Alegre: Globo, 1940, p. 104.

39 Antonio Álvares Pereira Coruja. Op. cit, p. 84. 
contou-se por centenas os estabelecimentos do gênero. Registram-se 316 tavernas, 38 botequins, cafés e restaurantes, 10 quiosques. ${ }^{40}$

Nos primeiros hotéis que a cidade conheceu, por volta de 1860, apareceram restaurantes que foram prestigiados: Aliança, Hotel Paris, Brésil, Siglo, todos oferecendo cardápios variados e bebidas importadas. Além dos hotéis, outros restaurantes atraíam a clientela masculina de escol, que começava a noite chic: Gruta Recreativa, à rua de Bragança, o restaurante Sferra, muito luxuoso, oferecendo pratos e vinhos italianos. Au Provôt, no arrabalde Menino Deus, apresenta grande novidade: ceia em companhia de mulheres alegres, em maioria estrangeiras, que começavam a chegar em busca de fortuna. ${ }^{41}$

Transformara-se a noite, com iluminação a gás. Os cafés multiplicaram como centros da socialidade masculina. Em 1870 só existia o Café da Fama, onde aparecia quem nāo prezasse a própria fama, conforme o velho Achyles, reclamando do que considerava excessos da vida noturna, no início de nosso século. ${ }^{42}$ No final do século passado, inúmeros cafés atraem clientela masculina: Java, Roma, América, Guarani, todos com mesas disputadas como afamados pontos de encontro. ${ }^{43}$ Percebe-se que tais ambientes eram freqüentados principalmente por gente mais endinheirada que, assim, pretigiava empreendimentos de caráter cosmopolita, em maioria fundados pela iniciativa de estrangeiros que se fixavam na cidade. $O$ gênero de estabelecimento é ainda lembrado por Costa Franco como cenário das "batalhas" urbanas ocorridas por ocasião da Revolução Federalista de 1893, visto que os cafés Java e América eram freqüentados respectivamente por simpatizantes dos dois partidos envolvidos na luta. ${ }^{44}$

Manteve-se por algum tempo a freguesia de casas-de-pasto, como aquela do Viarengo, freqüentado preferencialmente por operários e embarcadiços, onde se comia memorável fritada de camarôes e suculento mocotó, sob a vigilância de Garibaldi a cavalo. $\mathrm{O}$ quadro emoldurado na parede era símbolo para a construção de uma identidade italiana, com boas razões, entre os peninsulares no Rio Grande do Sul. O estabelecimento teria sido uma das últimas casas de pasto que resistiu aos novos tempos.

40 Enciclopédia dos municípios brasileiros, p. 68.

41 Athos Damasceno Ferreira. Op. cit, p. 102-3.

42 Achyles Porto Alegre. Flores entre ruínas, p. 19.

43 Anuário da Província - 1896 - para o ano de 1897. Graciano A. de Azambuja (dir.). Sérgio da Costa Franco. Porto Alegre na guerra civil: o "combate" dos cafés. In: Revolução de 1893. Porto Alegre: Secretaria Municipal de Cultura, Caderno Ponto e Vírgula, n. 3, 1993. 
Paris principalmente ditava uma noite mais agitada aos porto-alegrenses.

Além dos bailes nas novas sociedades que se multiplicavam, além dos teatros e dos cafés, as confeitarias começavam a atrair o elemento feminino. Saboreou-se chá com especialidades na Confeitaria da Alfândega, exibindo o figurino francês que substituiu as anquinhas pelo espartilho. Tornou-se imprescindível equilibrar enormes chapéus com enfeite alusivos à flora e à fauna, comprados à loja das madames Debise \& Chauvin, no Magasin de Modas ou au Bon Marché. ${ }^{45}$

\section{NOITE ILUMINADA}

Era o fin-de-siècle com seu acelerado cortejo de novidades, seja no vestuário, nas artes ou no modo de desfrutar a vida inclusive à noite.

Pois foi na noite que o século mudou que, na chaminé da Fiat Lux, um letreiro iluminou-se com a eletricidade: Salve o século $X X$. Porto Alegre apresentava o esboço da desejada e imaginada noite cosmopolita. Era cosmopolita ofooting feminino depois do chá das cinco em confeitaria da Rua da Praia. Ao escurecer, assistia-se na mesma rua o trotoir de belas mulheres de má reputação, verdadeiras musas da rapaziada que freqüentava as novas faculdades nos intervalos da noite, pois a boemia era prática assumida. O poeta Zeferino Brasil foi reconhecido como exemplo de boêmio nos fins do século, como assinala Maronese. ${ }^{46}$

Havia também os cafés-concerto. O Café Pátria já exibira em 1895, com enorme êxito, o grupo de Eduardo Moccia, apresentando zarzuelas. mesmo bem antes, em 1874, no palco do Hotel Fúlvio, já havia atuado a companhia dirigida por Madame Belloni que, segundo a imprensa da época, excitara toda a cidade, curiosa por conhecer tal gênero de espetáculo, ao estilo daqueles exibidos em Paris. O café-cantante estaria popularizado, teria atraído "distintas famílias da nossa melhor sociedade" ${ }^{47}$

Não menos atraentes sempre foram os espetáculos teatrais encenados por afamados grupos de fora que privilegiavam a cidade. Na virada do século, a Empresa Dramática Portuguesa apresentava no Theatro São Pedro,

Athos Damasceno. Op. cit, p. 73.

Luiz Antônio Goger Maronese. Espaços de sociabilidade e memória: fragmentos da "vida pública" porto-alegrense entre os anos de 1890 e 1930. Porto Alegre: PUCRS, Dissertação de mestrado, 1992.

47 Athos Damasceno Ferreira. Op. cit, p. 283. 
a grande Lucília Simões, em Francillon, de Alexandre Dumas Filho, assim como o ator Christiano de Souza, em Casa de Bonecas, de Ibsen. Ao mesmo tempo, o Politheama anunciava A Tosca e A Dama das Camélias, pela Companhia de Zaira Pieri Tiozzo, destacando que muitos atores eram provenientes de Buenos Aires. ${ }^{48}$

A sociedade se modificara e ficam evidentes as transformações no visual da cidade. Como demonstra Escosteguy, houve produção de novos espaços à beira do Guaíba durante o século passado, sendo que, durante a segunda metade do mesmo, a urbanização foi intensificada e surgem melhoramentos nos equipamentos urbanos..$^{49}$ Lembra Monteiro, contudo, que antes de 1924 não seria promovida uma reordenação do espaço global da cidade que mantinha traços do período colonial. Em aspectos arquitetônicos houvera transformaçōes promovidas pela iniciativa privada, o que não ocorrera no aspecto urbanístico. Sem dúvida, o Intendente Montaury promoveu melhorias que serviriam de ponto de partida para as grandes reformas urbanas promovidas por Otávio Rocha entre 1924 e 1928, quando foram abertas avenidas e criaram-se novas praças para compor o cenário urbano que representou "(...) de forma alegórica a dissolução de um passado e da tradição em favor de um ideal de modernidade $(. . .)^{\prime \prime} .{ }^{50}$

Lembra Weimer que, no Rio Grande do Sul, as cidades tornavam-se "uma festa celebrada em homenagem aos dirigentes patriarcais de impecável retidão moral". ${ }^{51}$ Estes dirigentes autoritários desejavam organizar sociedade que, entretanto, resistia em determinadas camadas, apesar da ação dos policiais de plantão à época que tratavam de exercer rigoroso controle.

A Polícia tratava de controlar o movimento noturno na cidade, cuidadosamente anotando nomes dos proprietários de residências ou estabelecimentos comerciais que insistissem em permanecer abertos até tardias horas. A estes seriam aplicadas as sansões. ${ }^{52}$

Era preciso ordenar certas práticas da população. O espaço público "deveria ser expressão de limpeza, beleza e ordem". Pechman enfatiza,

48 Jounal do Commercio. Porto Alegre, 10 de jan., 6 de fev. e 13 de mar. de 1900 . Museu Hippolito José da Costa.

49 Luís Felipe Alencastre Escosteguy. Espaços centrais à beira-rio em Porto Alegre (1809-1860). Porto Alegre: PUCRS, Dissertação de Mestrado, 1993.

50 Charles Monteiro. A inscrição da modernidade no espaço urbano de Porto Alegre (1924-1928). Porto Alegre: PUCRS, Dissertação de Mestrado, 1992.

51 Günter Weimer. A arquitetura. Porto Alegre: Ed. da Universidade/UFRGS, 1992, p. 88.

52 Seçāo de Polícia, 1901-2 - relatórios. Arquivo Muinicipal de Porto Alegre. 
porisso, a necessidade que se impunha no sentido de "criar uma nova moral: da ordem, da discipliona e da higiene" ${ }^{53}$

\section{Comportamentos indesejáveis}

A grande empresa moralizadora que tinha curso na Europa e que é exemplificada com a chamada era vitoriana teve seguidores gaúchos. Assinala Pesavento que Porto Alegre na virada do século, "(...) não oferecia perigos à vida e à propriedade (...) o centro urbano passara a oferecer ameaça à moral $\mathrm{e}$ aos bons costumes das famílias honradas". ${ }^{54}$

Não é à toa que o velho Achyles demonstra saudosismo, nos anos vinte. lamenta que as "danças finas", como a polca e o minueto, tenham entrado em desuso, substituídas pelo tango que "admite o deboche, o requebro, a umbigada pornográfica". Igualmente lamenta que o cinema tenha terminado com os serōes e saraus. As fitas faziam furor nas telas do Eden, do Apollo, do Metrópole, com preços acessíveis que permitiram a freqüência de "toda a gente - inclusive a arraia miúda". Insurgia-se o cronista com a escuridão da platéia, da qual se aproveitavam "os 'bolinas' para seu 'trabalhinho' audacioso, repulsivo e corruptor". ${ }^{55}$ As críticas de nada adiantaram, pois as salas de projeção foram multiplicadas, alcançando os mais distantes arrabaldes. Surgiram verdadeiras redes de cinemas, propriedade de imigrantes que investiam no ramo das diversões, reclamadas pelos habitantes de cidades.

Referindo-se à primeira década do século, Coaracy parece deplorar a inexistência de cabarés. Por volta de 1920, Achyles lamenta a sua proliferação, assim como as dos cafés.

O Centro dos Caçadores, afinal, tornara-se o símbolo do cosmopolitismo noturno. Nunca houve casa tão luxuosa. Artistas agenciadas em cidades maiores, quase sempre estrangeiras, incentivam ao consumo do champanhe. O reclame é sugestivo:

53 Robert Mosoes Pechman. Um olhar sobre a cidade: estudo da imagem e do imaginário do Rio na formação da Modernidade. In: Cidade-História. Salvador: Universidade Federal da Bahia. Faculdade de Arquitetura e Urbanismo/ ANPUH, 1992.

54 Sandra Jatahy Pesavento. O cotidiano da República. Porto Alegre: Ed. da Universidade/UFRGS, 1990, p. 113-14.

55 Achyles Porto Alegre. Serões de inverno. p. 160. Jardim de saudades. Porto Alegre:

Wiedmann, 1921, p. 113-14. 
"Porto Alegre se transforma! A vida noturna lhe intensifica o comércio e dá-lhe um aspecto de grande metrópole. E quem tem concorrido mais para este rápido progresso do que o Centro dos Caçadores? Fez daquela Porto Alegre monótona e dorminhoca de outrora uma cidade moderna, onde a elegância, o luxo e o gosto pela música de boulevard imperam". ${ }^{56}$

Mas não são propriamente ambientes deste tipo, freqüentados pelas elites, que preocupariam as autoridades, visto que eram por elas inclusive prestigiados.

No afã de manter a ordem, preocupavam a vadiagem e os vícios em geral entre as classes trabalhadoras que serão o alvo principal da repressão policial e das campanhas através dos jornais, que vituperam contra a prostituição, embriaguez e jogo.

É óbvio que casas mais modestas imitam o gran cabaret, com bebidas menos nobres e mulheres menos talentosas. Enquanto a Máscara anuncia atrações como La Princezita, Lilly Fleury, Nicolette, Pepita Montecarlo, Bella Lyra, O Jornal do Commercio noticia que, no Beco do Fanha, tradicional reduto de meretrício, Maria Joana e Maria Felipa armaram briga "mimoseando-se com os epithetos os mais deprimentes", e que, por isso, "as donairosas estrelas acompanharam os agentes de polícia." No mesmo dia, foram detidas seis pessoas por embriaguez, sendo que duas eram mulheres, como destaca o periódico, além de praças da Brigada Militar, que se encontravam jogando em casa residencial da rua Gen. Canabarro. ${ }^{57}$

Rigorosas medidas preventivas haviam sido tomadas em 1892, com nova regulamentação de impostos sobre os divertimentos, visando coibir aqueles considerados populares, os perigosos antros como denunciavam os jornais. Enquanto uma companhia lírica deveria pagar como imposto dez mil réis e sociedade particular cinqüenta mil réis, casa bailante ou sala que se alugasse para bailes custaria cem mil réis, baile público pagaria vinte e cinco mil e, sendo de máscaras ou fantasias, o imposto seria duplicado. ${ }^{58}$

Manter a ordem pretendida foi, portanto, tarefa empreendida com tenacidade pelas autoridades. Estatísticas revelam a desordem como delito de maior incidência, em sucessivos relatórios. No segundo semestre de 1904, por exemplo, registra-se como tal motivo para detenções, nos diversos

56 Máscara. Porto Alegre, Anno 1, n. 1,6 fev. 1918.

57 Porto Alegre, 10 jan. 1900.

58 Intendência Municipal, Seção de Polícia - Leis Municipais, 1892-1900 - Art. 1², § Arquivo Histórico de Porto Alegre. 
postos policiais da cidade, 592 casos de desordem, 169 casos de prisão por embriaguez, 106 por embriaguez e desordem, 61 por furto, 33 por agressão com ferimentos, 1 por homicídio, 5 por desobediência, 35 por ofensas à moral e 95 por outros crimes, num total de 1097 prisões efetuadas. Logo, mais da metade das detenções refere-se a desordens, sendo fácil inferir sobre a campanha que se desenvolvia. ${ }^{59}$ De outra parte, observa-se que 516 presos são de nacionalidade brasileira, seguidos por 38 italianos, 19 alemāes, 8 polacos e 11 de outras nacionalidades. Série documental referente à primeira década do século confirma a tendência, evidenciando que na rubrica outras nacionalidades aparecem com significativa freqüência espanhóis, portugueses, austríacos, árabes, argentinos, uruguaios, ingleses, franceses e russos.

Sem dúvida, tornara-se conturbada a noite na virada do século. Entre 1893 e 1896, entre seis processos que tramitaram no Tribunal de Júri, quatro estão relacionados a vícios e desordens que têm por cenário a noite.

Numa madrugada de fevereiro de 1893, Patrício, com 17 anos, teria assassinado a tiros Osvaldo, integrante de um grupo de jovens embriagados que ameaçavam arrombar a porta da casa da mãe do acusado, Isabel, paraguaia, solteira, residente à rua Riachuelo. Em fevereiro de 1896, Vittorio, natural de Turim, casado, empregado no vapor Garibaldi, é um dos acusados pelas mortes de Augusto e Giovanni, operários, em briga de botequim à rua Clara, onde houvera danças, carteado e muita bebida. No mesmo mês e ano, em baile que se realizava na Floresta, o menor Henrique fora agredido por indivíduo embriagado que provovia arruaças. Em abril, Antonio, empregado da Companhia de Fantoches, com 16 anos, arrombou porta de armazém, pela madrugada, e foi encontrado pela manhã, dormindo embriagado no telhado.

A leitura de processos criminais, também confirma a significativa presença de estrangeiros em baixas camadas sociais. Tal presença está a indicar a atração que a cidade exercia, sobretudo pelo desenvolvimento comercial e industrial que se verificava no período e a decorrente ampliação do mercado de trabalho.

Tornara-se polifônica a cidade, suas imagens estavam a refletir relações sociais e culturais condicionadas por diferentes e complexos grupos humanos. São precisamente as diferenças que contribuíram para esboçar um novo visual noturno para Porto Alegre. Não existe mais uma só voz que

59 Id. Ibid. Relatório dos trabalhos no Segundo Semestre - 1904 - pos. 5B5 - Arquivo Histórico de Porto Alegre. 
representará a sí mesma, mas diferentes vozes em contradição entre si. A cidade, então, precisaria começar a ser narrada por um coro polifônico, como ensina Canevacci, coro no qual "os vários itinerários musicais ou os materiais sonoros se cruzam se encontram e se fundem, obtendo harmonias mais elevadas ou dissonâncias..."

\section{CONSIDERAÇÕES FINAIS}

O espaço que se investiga é o da cidade de Porto Alegre e o tempo está focalizado em duas dimensōes, a saber, é tempo noturno, quando tranformaçōes nas socialidades se apresentam com maior intensidade; é na virada do século, quando a capital do Rio Grande do Sul passa por acelerado processo de mudanças que acrescenta elementos da modernidade no meio ubano.

Pretendeu-se analisar mudanças de comportamento entre os porto-alegreses com referência à utilização do tempo noturno.

Observa-se que, durante longo período, os divertimentos públicos praticamente se restringem aos domingos, à luz do dia, protagonizadas por gente comum. Representantes das elites, com excessão das festas religiosas, quando promovem divertimentos à noite, o fazem em ambientes privados. Há indícios do antigo medo associado à escuridão, com relação à noite porto-alegrense; interessante seria investigar até que ponto o medo e a superstição foram reforçados junto às classes populares, no sentido de coibir formas de divertimento noturno.

Com o decorrer do tempo, surgiram modelos de socialidades públicas identificados com o cosmopolitismo que fazia parte do imaginário de modernidade, entendido como compatível à cidade que apresentava alterações econômicas e sociais de vulto, inclusive com o surgimento de uma burguesia comercial e industrial significativa, em maioria de origem estrangeira, que estava a demonstrar a expansão das relaçōes capitalistas. Novos hábitos passaram a ser difundidos e apontavam para espaços fechados de socialidade. Apareceram cafés, confeitarias, cabarés, que deveriam ser freqüentados por gente civilizada, capaz de expressar sinais da linguagem cosmopolita.

60 Massimo Canavacci. A cidade polifônica: ensaio sobre a antropologia da comunicação urbana. São Paulo: Studio Nobel, 1993. p. 15. 
Assim, torna-se excludente o novo modelo propugnado à socialidades noturnas, rigorosamente controladas, sofrendo rigorosa repressão os que no modelo não se inserem.

No contexto, o discurso de Achylles Porto Alegre é sobremaneira importante por ser autêntico. Sua expressão, carregada de melancólico saudosismo e de cólera, demonstra tendência a uma apresentação natural, distante das representações sociais que se impunham à época. Ressente-se o velho contra as formas de divertimento vigentes no início do século $\mathrm{XX}$, de um modo geral, ainda que lamentando sejam os novos espaços fechados para sociabilidades públicas compartilhados pela arraia miúda. Em suma, seus meios emocionais de expressão evidenciam que não fora capaz de aprender e usar os sinais da linguagem cosmopolita já em voga.

É importante salientar outra inferência realizada a partir da investigação realizada, assunto que merecerá maior atenção no futuro. No caso de Porto Alegre, a nova imagem da cidade noturna começa a ser construída através de empreendimentos privados, em maioria por iniciativa de estrangeiros que se fixam na capital em grande número, desde meados do século passado. Antes, portanto, que acontecessem as grandes reformas que efetivamente transformaram a estrutura do meio urbano, eliminando o perfil de cidade colonial.

Outra aspecto a destacar é que, apesar das campanhas moralizadoras e da efetiva repressão policial, a atividade popular noturna só fez crescer. $O$ divertimento se expande pelas centenas de botequins, quiosques e bailes populares, paralelo às soirées da Sociedade Esmeralda, da Germânia ou da Vittorio Emanuelle, que pagavam menos impostos, ou dos banquetes no Grand Hotel, no Club do Commercio.

Vale lembrar o pensamento de Maffesoli: a sociedade não é jamais homogênea e não está submetida à razão. É mistura de sentimentos, paixões, imagens e diferenças que dão oportunidade a múltiplas experiências.

Os porto-alegrenses, em diferentes tipos de ambientes, apreciaram o vaudeville, dançaram novas coreografias, ao som do refrão que Athos Damasceno preservou:

"Abaixo o tamanca, bradai com afã

E viva a botina, sedosa e franzina

Que puxa o cancã"

O tango invadiria todos os ambientes, com seus passos sugestivamente eróticos. 
Quando as lâmpadas elétricas foram acesas nas ruas, já eram arraigados os hábitos sociais noturnos, ampliados à medida que se ampliava a claridade, pois se tornaram mais fáceis e seguros os percursos. Também em Porto Alegre tornou-se efetiva a conquista generalizada do tempo noturno na belle époque dos gaúchos. 